\title{
PERAN DAN KONTRIBUSI OIF UMSU DALAM PENGENALAN ILMU FALAK DI SUMATERA UTARA
}

\author{
Muhammad Qorib*, Zailani*, Radiman*, Amrizal**, Arwin Juli Rakhmadi* \\ *Universitas Muhammadiyah Sumatera Utara \\ **Universitas Negeri Medan \\ Email: muhammadqorib@umsu.ac.id HP; 081283992595
}

\begin{abstract}
Astronomy is counted as a natural science that always gets the most attention of humans all the time. Lately, in Indonesia began to appear astronomical observatories that examine various things. The Falak Observatory of the University of Muhammadiyah North Sumatra (OIF UMSU) is one that has played an important role in the development of astronomy in Indonesia, especially in North Sumatra. In this observatory there are classical and modern astronomical tools. Among the role and contribution of this observatory is to provide information for students about the phenomenon and importance of astronomy, then training for students, astronomy studies, and others. The existence of this observatory is basically an appreciation of science and technology that are part of civilization.
\end{abstract}

Keywords: Astronomy, Observatory, OIF UMSU

\begin{abstract}
Abstrak
Ilmu falak terhitung sebagai sains alam yang selalu mendapat perhatian besar manusia sepanjang waktu. Belakangan ini di Indonesia mulai muncul observatorium-observatorium astronomi yang mengkaji berbagai hal. Observatorium Ilmu Falak Universitas Muhammadiyah Sumatera Utara (OIF UMSU) adalah salah satu yang telah memainkan peran penting dalam pengembangan ilmu falak di Indonesia, khususnya di Sumatera Utara. Di Observatorium ini terdapat alat-alat astronomi klasik dan modern. Diantara peran dan kontribusi observatorium ini adalah memberikan informasi bagi para pelajar tentang fenomena dan arti penting astronomi, lalu pelatihan bagi para mahasiswa, pengkajian astronomi, dan lainnya. Keberadaan observatorium ini pada dasarnya adalah apresiasi terhadap sains dan teknologi yang merupakan bagian dari peradaban.
\end{abstract}

Kata kunci: Ilmu falak, Observatorium, OIF UMSU

\section{PENDAHULUAN}

Ilmu falak atau ilmu astronomi adalah pengetahuan alam semesta yang terus dikaji dan dipelajari manusia sepanjang waktu. Hal ini karena fungsi dan kegunaannya berhubungan dengan aktivitas manusia baik terkait dengan ibadah maupun aktivitas sosial. 
Di kalangan ulama dan ilmuwan abad pertengahan, ilmu falak adalah suatu cabang pengetahuan yang mengkaji keadaan benda-benda langit dari segi bentuk, kadar, kualitas, posisi dan geraknya. Sementara itu hai'ah secara etimologi bermakna keadaan sesuatu baik bersifat nyata (mahsūs) maupun logis (ma'qūl) (Majma' al-Lughah al'Arabiyyah, 2008). Keadaan nyata maupun logis ini antara lain disitir dalam QS. alMa'idah [05] ayat 110. Menurut Morlan (2005) Keadaan (hai'ah) dalam pengertian astronomi bermakna susunan alam semesta (bunyah al-kawn). Dalam khazanah intelektual Islam klasik, hai'ah (astronomi) adalah disiplin ilmu yang mengkaji bendabenda langit yang berkaitan dengan tata susun dan urutan orbit-orbit benda langit, kuantitas planet-planet dan konfigurasi rasi-rasi bintang dalam jarak, kadar, gerak, dan lain-lain (Basyra, 2008). Secara historis, hai'ah adalah terminologi orisinal yang muncul di peradaban Islam sejak pertengahan abad 3/9 (Butar-butar, 2015). Pengamatan (observasi) benda-benda langit adalah bagian integral dalam ilmu falak, pengamatan sendiri lazimnya dilakukan dalam sebuah observatorium (al-marshad).

\section{METODE}

Penelitian ini merupakan penelitian kualitatif, yakni peneliti menekankan pada makna, bukan pada pengukuran data. Penggunaan penelitian kualitatif dimaksudkan untuk mengetahui Peran dan Kontribusi OIF UMSU dalam Pengenalan Ilmu Falak di Sumatera Utara.

\section{HASIL DAN PEMBAHASAN}

\section{Terminologi Ilmu Falak}

Ilmu falak sebagai ilmu yang mengkaji benda-benda langit memiliki banyak istilah, antara lain: 'ilm an-nujūm, shinā'ah an-nujūm, shinā'ah at-tanjīm, 'ilm attanjīm, 'ilm al-ahkām, 'ilm hai'ah al-'âlam, 'ilm hai'ah al-aflāk, 'ilm al-aflāk wa annujūm, 'ilm al-falak, 'ilm al-hai'ah, al-asthrūnumiyā, al-anwā', dan ar-rashd (AlMukmin, 1991). Lima terminologi pertama ini terhitung terlarang (haram), namun di era abad pertengahan merupakan nomenklatur dari ilmu astronomi (ilmu falak). Falak dan hai' ah beserta istilah yang mengiringinya adalah yang paling banyak digunakan, istilahistilah ini merujuk pada makna pengkajian langit yang tidak berbias astrologi. 


\section{Observatorium}

Observatorium (Arab: al-marshad, al-marāshad), berasal dari kata ar-rashd yang bermakna yarqub atau taraqqub, yaitu menjaga atau mengawasi (Manzhur, t.t). Dalam Maqūyīs al-Lughah disebutkan bahwa kata rashd berasal dari kata ra-shad-dal, yang bermakna “at-tahayyu' liriqbah syai' 'alā maslakihi” (mempersiapkan sesuatu untuk mengantisipasi di dalam perjalanan). Sedangkan al-marshad bermakna mauqi' ar-rashd atau maudhi' ar-rashd, yaitu tempat menjaga atau tempat mengawasi. Dari makna literer ini dapat disimpulkan bahwa rashd berarti observasi, sedangkan marshad atau al-marshad berarti tempat observasi atau observatorium.

Secara terminologis, observatorium adalah sebentuk bangunan tempat dimana dilakukan pengamatan benda-benda langit yang mana pengamatan tersebut tercatat. Observatorium sangat identik dengan instrumen-instrumen yang beragam disamping lokasinya yang strategis. Dalam konteks modern, observatorium dapat dinyatakan sebagai warisan sekaligus sumbangan berharga dari peradaban Islam.

\section{Observatorium Pra-Islam}

Asal-usul dan atau cikal-bakal observatorium modern sejatinya telah ditemukan dan berakar dari observasi-observasi yang dilakukan sejak era pra-Islam. Hal ini oleh karena unsur integral dari sebuah observatoium adalah observasi (pengamatan). Dalam konteks zaman lampau, pengamatan merupakan hal penting karena berkaitan dengan keseharian manusia. Orang-orang di zaman lampau memiliki kebiasaan melakukan perjalanan, baik siang hari maupun malam hari untuk tujuan-tujuan tertentu. Untuk tujuan-tujuan itu mereka terbiasa membaca dan memahami gerak dan posisi bendabenda langit dan segenap fenomenanya di cakrawala sebagai pertanda dan pedoman di dalam perjalanan. Hal ini rutin mereka lakukan sepanjang hari dan sepanjang tahun.

Disadari atau tidak, aktifitas yang pada awalnya bersifat sosial-individual ini pada akhirnya menjadi unsur penting bagi lahirnya institusi observatorium. Di zaman lampau, aktifitas pengamatan merupakan bagian integral kehidupan manusia, baik terkait rutinitas ibadah, sosial, bisnis, maupun mitos-mitos (Butar-butar, 2015).

\section{Observatorium di Dunia Islam}

Pada awalnya, tujuan pendirian observatorium adalah dalam rangka pengkajian dan penelitian benda-benda langit semata. Namun seirng berjalannya waktu, 
observatorium memiliki jangkauan lebih luas yaitu menyelenggarakan pengajaran astronomi dan diskusi ilmiah. Namun oleh karena sifatnya yang sangat praktis dan empiris serta membutuhkan peralatan-peralatan khusus menyebabkan observatorium sebagai lembaga ilmiah tidak begitu menyebar luas di dunia Islam abad pertengahan bila dibanding dengan lembaga-lembaga sains lain seperti bait al-hikmah, perpustakaan dan rumah sakit maupun lembaga pendidikan Islam par excellence masjid dan madrasah (Asari, 2013). Secara garis besar, ada tiga fungsi observatorium di dunia Islam, yaitu: (1) pusat pengkajian langit, (2) institusi sains, dan (3) sarana penentuan ibadah.

1. Pusat Pengkajian Langit

Dengan tradisi observasi dan penelitian menyebabkan kajian astronomi menjadi lebih ilmiah dan intens. Sebelum itu, kajian mengenai langit lebih dominan bersifat spekulasi tanpa eksperimen ilmiah. Melalui kearifan tradisi observasi ini para astronom muslim merintis budaya metode eksperimental bagi pengembangan ilmu astronomi tanpa harus terjatuh dalam empirisme sebagaimana dalam astronomi Barat modern (Heriyanto, 2011). Selain terciptanya budaya ilmiah, observatorium juga mendorong lahirnya instrumen-instrumen astronomi baik hasil adaptasi-modifikasi terdahulu maupun yang baru.

\section{Institusi Sains}

Kehadiran observatorium sebagai institusi ilmiah merupakan tuntutan sosial masyarakat muslim. Diantara faktor munculnya institusi ini merupakan ekspresi sekaligus apresiasi terhadap warisan Yunani dan Hellenistik (Sayili, 1995). Dalam kehadiran awalnya, observatorium adalah model bagi sebuah organisasi sains, yang setidaknya ada dua faktor pemicunya. Pertama, bahwa observatorium sebagai institusi sains mampu mencerminkan sifat penelitian ilmiah melalui pengamatan alami yang terorganisir. Hal ini menjadi basis bagi perkembangan teori-teori ilmiah yang terus berkembang dan memiliki karakter. Kedua, observatorium sebagai organisasi sosial mencerminkan kekhasannya yang tergambar dalam praktik kolektif dan kerjasama antar astronom (Al-Qadiri, 2009). Dua faktor ini memberi pengaruh bagi kemajuan pengetahuan astronomi di dunia Islam.

3. Sarana Penentuan Waktu Ibadah

Benda-benda langit (khususnya Bulan dan Matahari) merupakan obyek utama penelitian sebuah observatorium. Ibadah-ibadah penting umat Islam (khususnya shalat 
dan puasa) sangat terkait dengan pergerakan dan fenomena benda-benda langit tersebut. Waktu-waktu shalat ditentukan berdasarkan fenomena Matahari. Untuk kepentingan ini, mengamati Matahari menjadi satu keharusan bagi umat Islam. Sementara itu penentuan awal bulan, baik menggunakan rukyat maupun hisab, keduanya menghendaki adanya pengamatan akan fenomena langit terkait terbit, terbenam, horison, dan lain-lain. Untuk dua ibadah ini (shalat dan puasa) menegaskan arti penting kehadiran dan keberadaan observatorium.

\section{Observatorium Era Modern}

Dalam konteks ideal, sebuah observatorium meniscayakan tiga pilar yang saling terkait, yaitu: (1) sumber daya manusia, (2) manajemen, dan (3) finansial. Tiga pilar ini berjalan secara bersamaan dan aktif-kolektif. Pilar pertama terkait dengan konsep, rancangan, ide, gagasan dan terobosan mengenai apa dan bagaimana observatorium dikembangkan. Sejumlah ahli (pakar) dengan spesialisasi astronomi mumpuni sangat diperlukan. Selanjutnya, konsep yang matang bila tidak dikelola secara baik maka ia tidak lebih sekedar idealisme dan obsesi dalam pikiran belaka. Manajemen diperlukan untuk mengelola ide-ide dan gagasan-gagasan itu untuk dapat diterapkan.

Dua pilar ini (sumber daya manusia dan manajemen) juga belum sempurna bila tidak didukung dengan kekuatan pendanaan terkait penyiapan sarana dan prasarana. Seperti diketahui, pengamatan langit adalah aktifitas yang sangat dinamis selain simultan. Diperlukan instrumen-instrumen pencari dan penjejak benda-benda langit yang memadai sesuai perkembangan zaman. Dalam kenyataannya, instrumen-instrumen ini (khususnya teleskop) terus berkembang sesuai perkembangan zaman. Oleh karena itu, kekuatan finansial mutlak diperlukan. Dan karena itu pula, kebijakan, kearifan, dan keyakinan pemimpin terkait alokasi biaya mutlak diperlukan.

\section{Observatorium Ilmu Falak UMSU}

Observatorium Ilmu Falak Universitas Muhammadiyah Sumatera Utara (disingkat OIF UMSU) adalah lembaga di UMSU yang bergerak di bidang ilmu falak (astronomi). OIF didirikan tahun 2014 berdasarkan SK Rektor UMSU (Dr. Agussani, MAP) nomor 1060/KEP/II.3-AU/UMSU/D/2014, dan diresmikan oleh Ketua MTT PP Muhammadiyah (Prof. Dr. H. Syamsul Anwar, MA). Selanjutnya pada Konvensi Nasional Indonesia Berkemajuan (KNIB) di Yogyakarta, 23 Mei 2016 M, OIF kembali 
diresmikan oleh Presiden RI (Joko Widodo) yang ditandai dengan penandatanganan prasasti.

OIF UMSU berada di lantai 7 gedung Pascasarjana UMSU dengan area seluas 25 x 55 meter. Adapun data dan posisi geografis OIF UMSU sebagai berikut:

Tabel 1. Posisi Geografis OIF UMSU

\begin{tabular}{ll}
\hline Lintang & $03^{\circ} 34^{\prime}{ }^{\prime} \mathrm{LU}$ \\
Bujur & $98^{\circ} 43^{\prime} \mathrm{BT}$ \\
Bujur Waktu & $105^{\circ}$ \\
Selisih GMT & 7 jam \\
Selisih Mekah & 4 jam \\
Jarak ke Ka'bah & $6658 \mathrm{KM}$ \\
Azimut Kiblat & $292^{\circ} 45^{\prime} 36^{\prime}$, \\
Ketinggian dpl & $36 \mathrm{~m}$ \\
Website & www.oifumsu.com \\
Halaman Facebook & Observatorium Ilmu Falak \\
& UMSU \\
Alamat & Jl. Denai No. 217 Kampus \\
& Pascasarjana UMSU (lt 7) \\
\hline
\end{tabular}

\section{Kelengkapan dan Instrumen}

Saat ini, di OIF UMSU terdapat 7 ruangan/area, yaitu: (1) ruang planetarium flat, (2) ruang diskusi, (3) ruang kepala, (4) kantor, (5) gudang, (6) ruang instrumen/perpustakaan, dan (7) taman. Adapun alat-alat astronomi sebagai terdapat di ruang instrumen terdiri dari gabungan alat-alat klasik dan modern, seluruhnya mencapai sekitar 150 alat. Teleskop adalah instrumen utama dan menjadi ikon observatorium. Saat ini OIF UMSU memiliki 11 unit teleskop dengan berbagai tipe dan ukuran. Teleskop ini digunakan baik untuk penelitian, pembelajaran, pameran, perlombaan, dan lain-lain. Selain teleskop, juga ada Teodolit (2 unit), GPS, SQM (4 unit), Rainwise (Weather Station), dan lain-lain.

Selain itu juga terdapat alat-alat astronomi klasik, yaitu alat-alat astronomi hasil karya para ilmuwan Muslim maupun pra-Islam dengan adaptasi dan modifikasi modern, antara lain: Rubu Mujayyab (8 unit), Jam Matahari (Mizwalah), Istiwain, Astrolabe, dan lain-lain. Sedangkan instrumen-instrumen yang ada di area taman, yaitu: Jam Matahari (2 unit), Rubu Mujayyab, Rainwise (Weather Station), Lubang Transit Matahari, SQM (2 titik), Tiang Rashdul Kiblat, Bola Dunia, Miniatur Tata Surya, All Sky Camera, Sliding Roof Ahmad Dahlan/Teleskop, dan Kubah Ahmad Dahlan/teleskop (2 unit). 
Alat-alat yang ada di taman ini menjadi keunikan dan daya tarik tersendiri bagi pengunjung (Tim OIF UMSU, 2017).

\section{Aktifitas}

Secara umum, aktifitas OIF UMSU adalah: penelitian, pengabdian, pelayanan publik (kunjungan sekolah dan masyarakat, kunjungan istimewa), seminar nasional dan internasional, serta diskusi internal. Sejauh ini penelitian yang telah dilakukan adalah: observasi fajar sadik dan syafak, observasi awal bulan, pengamatan benda-benda langit secara umum (Bulan, Matahari, Venus, Jupiter, Nebula, transit Merkurius, dan lainlain), dan penelitian kalender Islam global.

Sedangkan pengabdian kepada masyarakat diantaranya berupa akurasi dan pengukuran arah kiblat masjid-masjid, mushalla, lapangan, perkantoran, dan lain-lain. Sampai saat ini OIF UMSU telah mengukur dan mengakurasi arah kiblat sekitar 190 tempat (lokasi) (Tim OIF UMSU, 2017).

\section{Tantangan}

Observatorium sebagai mengkaji benda-benda langit adalah aktifitas yang bersifat simultan, dinamis, dan berkelanjutan. Juga, aktifitas yang di dalamnya diperlukan sinergi dan kerja sama. Hal ini meniscayakan tersedianya sumber daya manusia yang unggul dan konsisten. Bagaimanapun, kesediaan dan ketersediaan tokoh yang mendalami observatorium dan menguasai ilmu falak dari berbagai aspek mutlak diperlukan. Observatorium di era modern juga meniscayakan tata kelola (manajemen) yang baik. Mobilitas dan tuntutan sosial yang tinggi sekali lagi meniscayakan adanya manajemen yang baik. Selain itu, aspek finansial juga merupakan hal penting dan harus terpenuhi. Seperti diketahui, instrumen-instrumen astronomi (khususnya teleskop) terus berkembang sesuai perkembangan zaman. Perkembangan itu sendiri meniscayakan ketersediaan dana yang besar. Problem yang lazim dihadapi, khususnya di kalangan swasta, adalah pergantian estafet kepemimpinan sebuah lembaga yang dapat berakibat bergesernya cara pandang dan berubahnya orientasi.

\section{KESIMPULAN}

Observatorium adalah warisan berharga peradaban Islam. Fungsi utama observatorium adalah sarana pengkajian langit, institusi sains, dan sarana penentuan ibadah. Eksistensi observatorium di era modern (khususnya di sebuah universitas) 
meniscayakan tiga hal fundamental, yaitu sumber daya manusia, manajemen, dan pendanaan.

Observatorium Ilmu Falak UMSU telah berperan di tengah masyarakat Sumatera Utara dan terus bertekad mengembangkan dan memperkenalkan ilmu falak di tengah masyarakat. Dalam konteks UMSU, pendirian observatorium merupakan spirit "Islam Berkemajuan", dan dalam konteks universal merupakan bagian dari upaya mempertautkan dimensi ideal wahyu dan peradaban manusia.

\section{DAFTAR PUSTAKA}

------. 2016. Khazanah Astronomi Islam Abad Pertengahan. Purwokerto: UMP Press, cet. I.

------. 2016. Urgensi dan Kontribusi Observatorium di Era Modern. Jurnal Tarjih, vol 13, Nomor 2.

Al-Mu'min, Abdul Amīr. 1413/1991. at-Turāts al-Falaky 'Inda al-'Arab wa alMuslimīn wa Atsāruhu fì 'Ilm al-Falak al-Hadìts. Aleppo: Universitas AleppoSuriah.

Al-Qādirī, Abdul. 2009. Mu'assasah 'Ilm al-Falak al-'Araby. Suriah: Wizarah atsTsaqafah al-Hai'ah al-'Ammah as-Suriyyah li al-Kitab.

Asari, Hasan. 2013. Menyingkap Zaman Keemasan Islam. Bandung: Ciptapustaka, cet. III.

Basya, Ahmad Fuad. 1429/2008. al- 'Athā' al-'Ilmy li al-Hadhārah al-Islāmiyyah wa Atsāruhu fì al-Hayāh al-Insāniyyah. Cairo: Maktabah al-Imām al-Bukhārī, cet. I)

Butar-Butar, Arwin Juli Rakhmadi. 2015. Observatorium Sejarah dan Fungsinya di Peradaban Islam. UMSU Press, cet. I.

Heriyanto, Husain. 2011. Menggali Nalar Saintifik Peradaban Islam. Jakarta: Mizan, cet. I.

Majma' al-Lughah al-'Arabiyyah, al-Mu’jam al-Wasīth. Cairo: Maktabah asy-Syurūq ad-Dauliyyah, cet. IV, 1429/2008.

Manzhūr, Ibn. Lisān al- 'Arab, j. 3. Cairo: Dār al-Ma'ārif, t.t.

Morlan, Regis. 2005. Muqaddimah fì 'Ilm al-Falak, dalam "Mausū'ah Tārīkh al-'Ulūm al-‘Arabiyyah”, j. 1. Beirut: Markaz Dirāsāt al-Wahdah al-‘Arabiyyah, cet. II 
Rambe, Syahril. 2019. Peran Observatorium Ilmu Falak UMSU Dalam Pendidikan Islam di Kota Medan. Tesis: Pascasarjana UINSU Medan.

Rohmah, Nihayatur. 2018. Observasi dan Observatorium (Peluang dan Tantangan Rukyatul Hilal di Indonesia). Al-Mabsut (Jurnal Studi Islam dan Sosial), vol. 12, No. 2.

Sayili, Aidin. 1995. al-Marāshad al-Falakiyyah fì al-'Ālam al-Islāmy. Kuwait: Mua'ssasah al-Kuwait li at-Taqaddum al-'Ilmy, cet. I.

Tim OIF UMSU. 2017. Ensiklopedi OIF UMSU. Medan: OIF UMSU, cet. I. 